\title{
Vase Life and Quality of Cut Flower by Wet Solution according to Shipping Period and Temperature in Dendranthema grandiflorum 'Jinba'
}

\author{
Yong Seung Roh ${ }^{1}$, In Kyung Kim ${ }^{1}$, and Yong Kweon Yoo ${ }^{1,2 *}$ \\ ${ }^{1}$ The Institute of Natural Resource Development, Mokpo National University, Muan 58554, Korea \\ ${ }^{2}$ Department of Horticultural Science, College of Natural Science, Mokpo National University, Muan 58554, Korea
}

\section{ABSTRACT}

This study was conducted to examine the effects of wet storage solution, transport period and temperature on vase life and quality of cut flowers in standard chrysanthemum 'Jinba'. Immediately after transport, the fresh weight and flower diameter of cut flowers did not show a difference according to wet storage solutions regardless of the transport period, but as the transport period increased, the fresh weight and flower diameter increased. The flower bud stage at harvest was maintained due to the small changes in flower diameter, and the freshness of leaves was better when transported at $5^{\circ} \mathrm{C}$ than at $25^{\circ} \mathrm{C}$. When transported at $25^{\circ} \mathrm{C}$, the longer the transport period, the lower the quality of cut flowers as some petals opened up and showed early flowering after transport. In preservative solutions, quality of cut flowers transported at $25^{\circ} \mathrm{C}$ was lower than that at $5^{\circ} \mathrm{C}$ due to fresh weight and diameter according to the longer transport period. The vase life of cut flowers was 1.0 day, 0.8 day, and 7.3 days longer when transported for 3,5 , and 7 days respectively at $5^{\circ} \mathrm{C}$ than at $25^{\circ} \mathrm{C}$. The quality of cut flowers was better due to increase in fresh weight and flower diameter, as well as vase life in wet storage solutions of $\mathrm{ClO}_{2}$ and Chrysal OVB than in tap water, regardless of transport period and temperature. There was no difference in fresh weight and vase life between $\mathrm{ClO}_{2}$ and $\mathrm{Chrysal} O V B$, but flower diameter was greater in $\mathrm{ClO}_{2}$ than in Chrysal OVB. Therefore, for long-term transport of cut standard chrysanthemum 'Jinba', wet storage transport in $\mathrm{ClO}_{2}$ at $5^{\circ} \mathrm{C}$ was found effective in maintaining the quality and vase life of cut flowers.

Keywords: Chrysal OVB, $\mathrm{ClO}_{2}$, standard chrysanthemum, wet shipping

\section{Introduction}

Chrysanthemums are third most exported cut flowers, and those worth $\$ 1.441$ million were exported in 2018, mostly to Japan (Ministry of Agriculture, Food, and Rural Affairs, 2019). However, exports have decreased continuously since exporting $\$ 13.802$ million in 2010, resulting in $\$ 1.441$ million in 2018. The decrease in exports is caused by the depreciation of the Japanese yen, increase in operating expenses, and rise in the prices of agricultural materials, but one cause can be the fact that the wilting of cut flowers due to transport in dry storage in the export process deteriorates flower quality, thereby reducing preference of consumes in the importing countries. Transport in dry storage causes air to flow into the vascular system of cut flowers, suppressing water absorption even when put in a preservative solution (Ichimura et al., 2009). It also prevents flowers from absorbing water during transport, causing water stress and making the leaves of cut flowers wilt (Roh et al., 2018). For cut roses, overseas export or long-term transport is

\footnotetext{
This research was supported by a research grant (316016-04-4-HD030) from the Korea Institute of Planning and Evaluation for Technology in Food, Agriculture, and Forestry (IPET).

Received: December 10, 2019, Revised: December 11, 2019, Accepted: December 12, 2019

First author: Yong Seung Roh, noyong2@mokpo.ac.kr, (D) https://orcid.org/0000-0002-6628-0709

*Corresponding author: Yong Kweon Yoo, yooyong@mokpo.ac.kr, (D) https://orcid.org/0000-0001-6884-163X
} 
carried out in wet storage. Varieties such as 'Lovely Lydia', 'Bridal Pink', and 'Red Sandra' showed greater flower diameter when the cut flowers were transported in wet storage solutions than when they were transported in dry storages, and showed less bentnecks and longer vase life as well (Bang, 1999; Hu et al., 1998; Lee, 2011). Moreover, studies were conducted on cut lilies as well regarding wet storage transport to maintain freshness when exporting from Korea to Japan. For varieties such as 'Medusa' and 'Siberia', the cut flowers maintained higher fresh weight and flower diameter when transported in wet storage than dry storage, and also showed longer vase life (Lee and Kim, 2016; Lim et al., 2016). The ingredients of wet storage solutions used for wet storage transport vary depending on the cut flowers, but bactericides are generally used in all solutions. Bactericides not only suppress bacterial propagation caused during long-term transport but also prevent vascular occlusion of cut flowers by bacteria (Roh et al., 2018; van Doorn et al., 1986).

Moreover, transport temperature and period must be considered in long-term transport of cut flowers. High transport temperature promotes leaf respiration and transpiration, causing overconsumption of nutrients and damages from dryness, thereby deteriorating the quality of cut flowers. On the other hand, lowering transport temperature suppresses respiration and prevents loss of nutrients, thereby increasing flower diameter and vase life (Cevallos and Reid, 2001; Petridou et al., 2001). Cut chrysanthemum 'Baekma' also maintained higher fresh weight at $5^{\circ} \mathrm{C}$ transport condition than $35^{\circ} \mathrm{C}$ when exporting to Japan, as well as longer flower diameter (Yoo and Roh, 2015).

In general, it takes approximately 3-7 days to harvest cut flowers from farms and ship them to Japan. Roh et al. (2018) claimed that it takes 4-5 days to export standard chrysanthemum 'Baekma' to Tokyo, Japan, and when transporting in wet storage, using $\mathrm{NaOCl}$ and $\mathrm{ClO}_{2}$ as wet storage solutions reduces wilting of leaves and maintains high quality of cut flowers.

Therefore, this study examined the effects of using $\mathrm{ClO}_{2}$ and Chrysal OVB as wet storage solutions on the quality and life of cut flowers according to transport temperature and period when shipping standard cut chrysanthemum 'Jinba'.

\section{Research Methods}

As materials, the cut chrysanthemum 'Jinba' variety with buds sized $1.7 \pm 2 \mathrm{~cm}$ cultivated in farms of Muan-gun, Jeollanam-do is harvested and used. The flowers were put in tap water immediately after harvest, transported to Mokpo National University on a $5^{\circ} \mathrm{C}$ refrigerator car, and stored in $5^{\circ} \mathrm{C}$ cold store for 1 day. After storage, stalks were cut by $80 \mathrm{~cm}$, and the cut flowers were put upright in the plastic containers with wet storage solutions inside the corrugated cardboard box. For wet storage solutions, we used tap water (control), $2 \mathrm{mg} \cdot \mathrm{L}^{-1} \mathrm{ClO}_{2}, 3 \mathrm{ml} \cdot \mathrm{L}^{-1}$ (VitalOxide ${ }^{\circledR}$, Danbibio Ltd., Korea), and Chrysal OVB (Chrysal International B.V., Netherlands). After simulated transport in 5 and $25^{\circ} \mathrm{C}$ storage for 3, 5 and 7 days, we examined the quality of cut flowers such as flower diameter and fresh weight. Then, 5 cut flowers for each treatment were put in three repeats in $50 \mathrm{mg} \cdot \mathrm{L}^{-1} \mathrm{NaOCl}$ preservative solution, after which we examined the quality. For quality of cut flowers, we examined fresh weight and flower diameter using the method by Yoo and Roh $(2015)$, in the $20^{\circ} \mathrm{C}$ constant temperature room with relative humidity of $50 \%, 12$ hours of photoperiod a week, and $80 \mu \mathrm{mol} . \mathrm{m}^{-2} \cdot \mathrm{s}^{-1}$ of light, and evaluated vase life every day.

\section{Results and Discussion}

\section{Quality of cut flowers immediately after transport according to transport period and temperature}

After harvesting cut flowers of standard chrysanthemum 'Jinba' and conducting simulated transport in wet storage solutions for 3, 5 and 7 days at the transport temperature of $5^{\circ} \mathrm{C}$ and $25^{\circ} \mathrm{C}$, we examined the quality of the cut flowers. On Day 3, there was no difference in leaf freshness according to transport temperature $5^{\circ} \mathrm{C}$ and $25^{\circ} \mathrm{C}$, and wet storage solution (Fig. 1). Fresh weight and flower diameter did not show a difference depending on wet storage solutions, but the fresh weight was $102-104 \%$ in those treated at $5^{\circ} \mathrm{C}$ and $109-110 \%$ in those treated at $25^{\circ} \mathrm{C}$, indicating that fresh weight increased 6-7\% more when transport temperature was high (Fig. 2A). Moreover, flower diameter was 108-115\% 

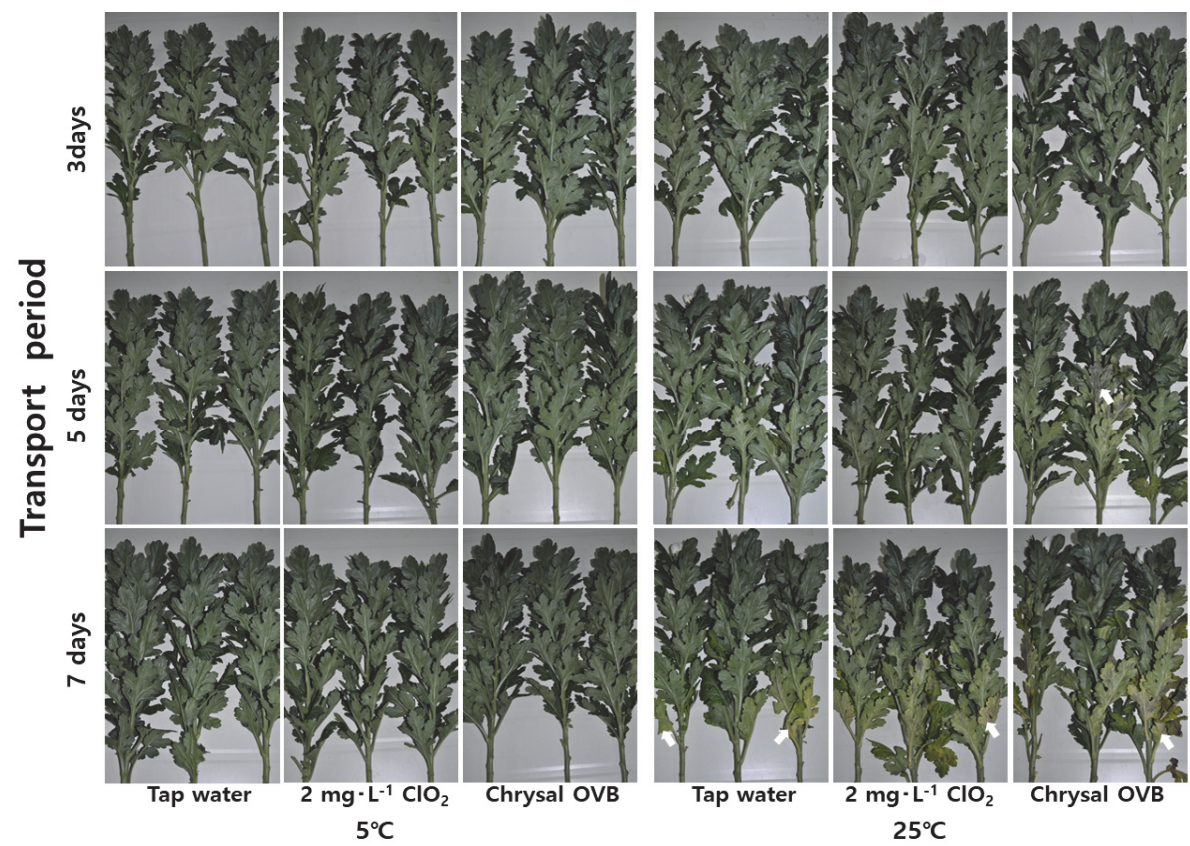

Fig. 1. Quality of cut flowers of standard chrysanthemum 'Jinba' after simulated transport for 3,5 , and 7 days at $5{ }^{\circ} \mathrm{C}$ and $25^{\circ} \mathrm{C}$ in wet shipping solutions (tap water, $\mathrm{ClO}_{2}$, and Chrysal OVB). Arrows indicate withered leaves.
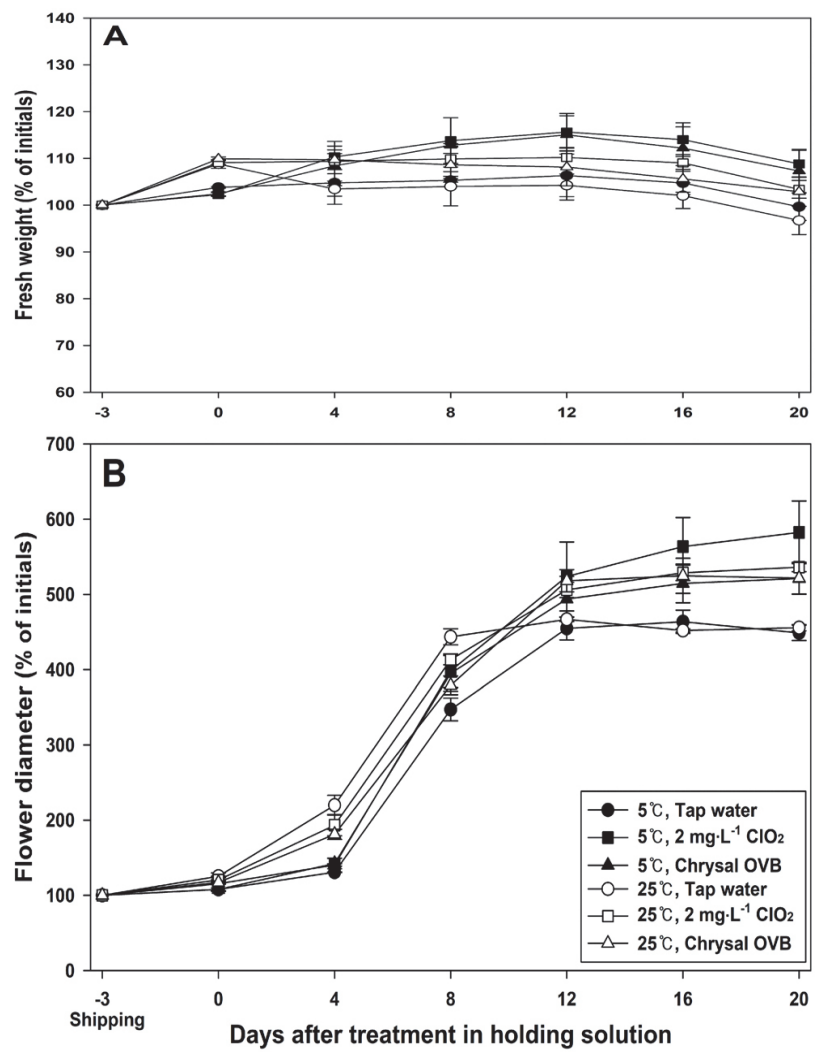

Fig. 2. Changes in fresh weight (A) and flower diameter (B) of standard chrysanthemum 'Jinba' after simulated transport for 3 days at $5^{\circ} \mathrm{C}$ and $25^{\circ} \mathrm{C}$ in wet shipping solutions(tap water, $\mathrm{ClO}_{2}$, and Chrysal OVB). Vertical bars represent the standard errors $(n=3)$. at $5^{\circ} \mathrm{C}$ after transporting for 3 days, and $117-125 \%$ at $25^{\circ} \mathrm{C}$, showing that flower diameter increased $9-10 \%$ more when transport temperature was high, which partially opened the flower buds and thus slightly decreased merchantability (Fig. 2B).

When transported for 5 days, there was no quality difference depending on wet storage solutions at $5^{\circ} \mathrm{C}$ transport temperature, but some leaves showed chlorosis in Chrysal OVB wet storage solution at $25^{\circ} \mathrm{C}$ (Fig. 1). Fresh weight and flower diameter did not show a difference depending on wet storage solutions, but fresh weight was 104-105\% at $5^{\circ} \mathrm{C}$ and $111-113 \%$ at $25^{\circ} \mathrm{C}$, indicating that fresh weight was $7-8 \%$ greater when transport temperature was high, and $2-3 \%$ greater in general than the ones transported for 3 days (Fig. 3A). Moreover, flower diameter was greater at $25^{\circ} \mathrm{C}(140-146 \%)$ than $5^{\circ} \mathrm{C}(106-112 \%)$, and $34 \%$ greater than the ones transported for 3 days, which partially opened the flower buds and thus decreased merchantability (Fig. 3B).

When transported for 7 days, there was no difference in leaf freshness depending on wet storage solutions at $5^{\circ} \mathrm{C}$ transport temperature. At $25^{\circ} \mathrm{C}$, leaves at the bottom of the stems wilted or there was chlorosis on the flowers in generally all wet storage solutions, such as tap water, $\mathrm{ClO}_{2}$, 

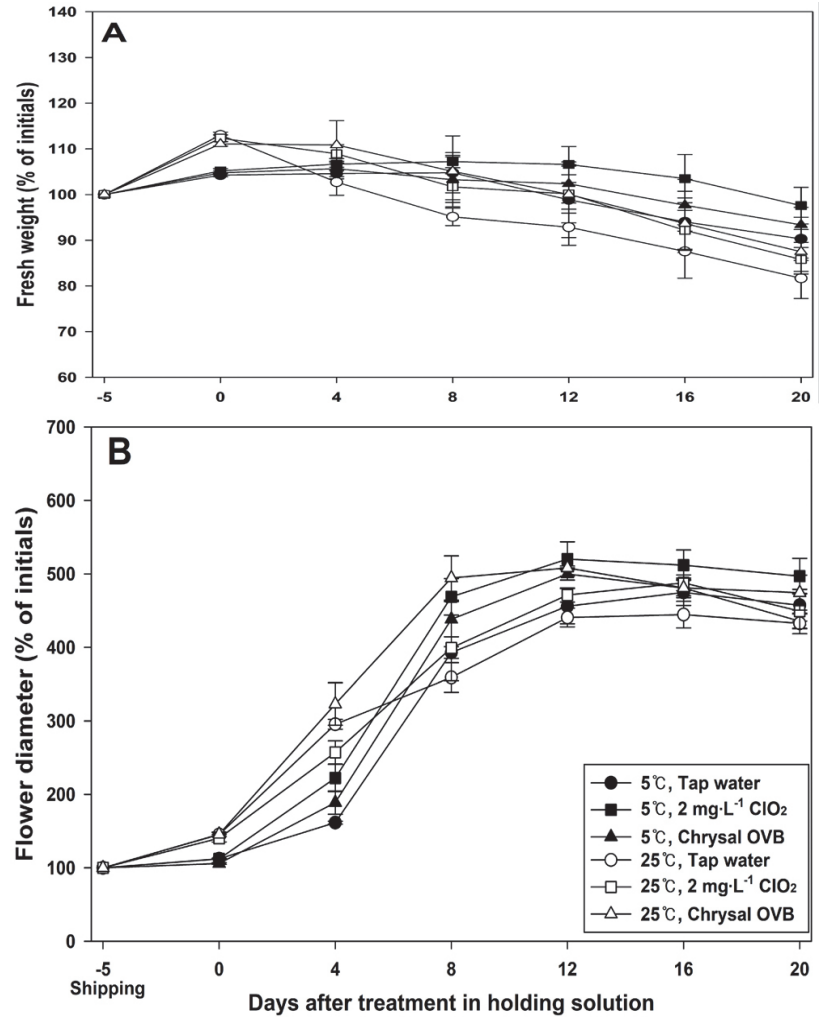

Fig. 3. Changes in fresh weight (A) and flower diameter (B) of standard chrysanthemum 'Jinba' after simulated transport for 5 days at $5^{\circ} \mathrm{C}$ and $25^{\circ} \mathrm{C}$ in wet shipping solutions (tap water, $\mathrm{ClO}_{2}$, and Chrysal OVB). Vertical bars represent the standard errors $(n=3)$.

and Chrysal OVB (Fig. 1). Fresh weight and flower diameter did not show much difference depending on wet storage solutions, but fresh weight was $104-105 \%$ at $5^{\circ} \mathrm{C}$ and $112-116 \%$ at $25^{\circ} \mathrm{C}$, indicating that fresh weight was $8-9 \%$ greater when transport temperature was high, and 1-3\% greater in general than the ones transported for 5 days (Fig. 4A). Moreover, flower diameter was $99-101 \%$ at $5^{\circ} \mathrm{C}$ and $168-173 \%$ at $25^{\circ} \mathrm{C}$, indicating that transporting for a long time at high temperature increases flower diameter by $70 \%$ from when the flower was first harvested, showing early flowering (Fig. 4B).

Therefore, when exporting cut chrysanthemum 'Jinba', it must be transported at $5^{\circ} \mathrm{C}$ regardless of transport period to maintain merchantability by preventing early flowering of buds, leaf wilting and chlorosis right after transport, and there was almost no difference depending on wet storage solution.
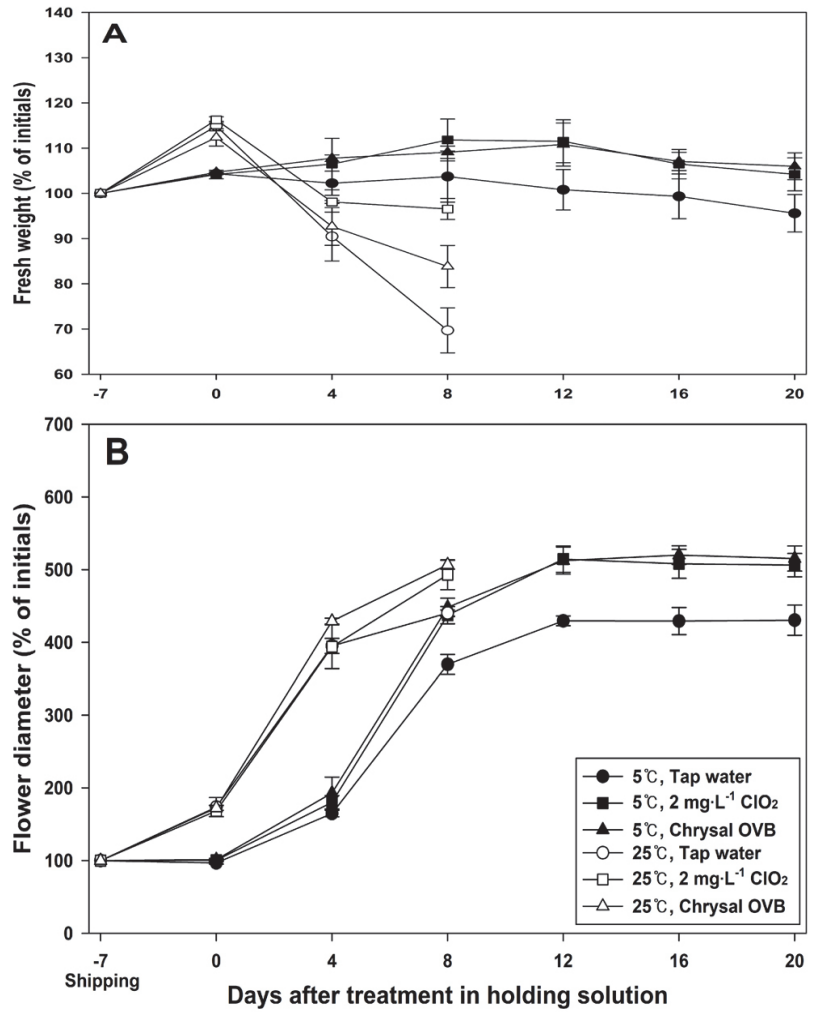

Fig. 4. Changes in fresh weight (A) and flower diameter (B) of standard chrysanthemum 'Jinba' after simulated transport for 7 days at $5{ }^{\circ} \mathrm{C}$ and $25^{\circ} \mathrm{C}$ in wet shipping solutions (tap water, $\mathrm{ClO}_{2}$, and Chrysal OVB). Vertical bars represent the standard errors $(n=3)$.

\section{Quality of cut flowers and vase life in preservative solutions according to transport period and tem- perature}

After harvesting cut flowers of standard chrysanthemum 'Jinba' and transporting them for 3 days, we put them in preservative solutions and examined the quality of the cut flowers. Fresh weight decreased slightly overall for cut flowers transported at $25^{\circ} \mathrm{C}$, and it showed a significant decrease in Day 4 when tap water was used as wet storage solution. Fresh weight slightly increased to $103 \%$ for the treatment in which tap water was used as wet storage solution at $5{ }^{\circ} \mathrm{C}$, whereas fresh weight remained higher in $\mathrm{ClO}_{2}$ and Chrysal OVB treatment, which increased to $115-116 \%$ in Day 12 and thus proved that water absorption went smoothly (Fig. 2A). Flower diameter of cut flowers transported at $25^{\circ} \mathrm{C}$ increased greatly until Day 8 in preservative solutions, showing bigger flower diameter than those trans- 
ported at $5^{\circ} \mathrm{C}$. However, since Day 12, flower diameter of those transported at $5^{\circ} \mathrm{C}$ was greater, and especially in Day 20, flower diameter was greater in $\mathrm{ClO}_{2}$ wet storage solution (580\%) than Chrysal OVB (521\%), showing excellent quality of cut flowers (Fig. 2B). Vase life was longest at $5^{\circ} \mathrm{C}$ in $\mathrm{ClO}_{2}$ (18.0 days) and Chrysal OVB (17.6 days), which was statistically significant compared to other treatments (Fig. 5A). Those transported at $25^{\circ} \mathrm{C}$ showed the longest vase life (17.4 days) in $\mathrm{ClO}_{2}$ (Fig. 6).

After harvesting cut flowers of standard chrysanthemum 'Jinba' and transporting them for 5 days, we put them in preservative solutions and examined the fresh weight. The results showed that, like the ones transported for 3 days, cut flowers transported at $25^{\circ} \mathrm{C}$ showed a slight decrease in fresh weight (Fig. 3A). Fresh weight decreased most greatly when tap water was used as wet storage solution, whereas there was not much difference in $\mathrm{ClO}_{2}$ and Chrysal OVB. At $5^{\circ} \mathrm{C}$, fresh weight was highest at $107 \%$ in Days 8-12 in $\mathrm{ClO}_{2}$, which remained higher than other treatments until day 20. However, fresh weight was $9 \%$ lower than those transported in $\mathrm{ClO}_{2}$ for 3 days at $5^{\circ} \mathrm{C}$, proving that transport period affected fresh weight of cut flowers (Fig. 3B). Flower diameter increased greatly until Day 4 in preservative solutions for those transported at $25^{\circ} \mathrm{C}$. From Day 8, the flowers showed greater flower diameter in $\mathrm{ClO}_{2}$ than tap water or Chrysal OVB, which increased up to $508 \%$ in Day 12. Cut flowers transported at $5^{\circ} \mathrm{C}$ showed
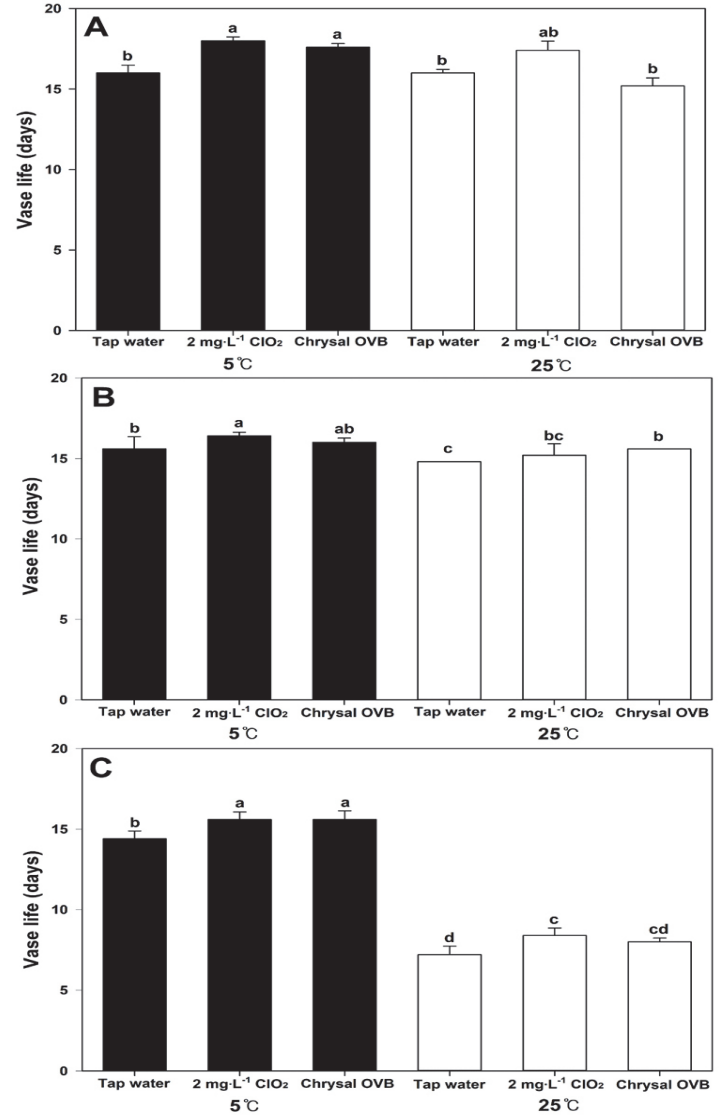

Fig. 5. Vase life of cut flower of standard chrysanthemum 'Jinba' after simulated transport for 3 days(A). 5 days(B), and 7 days $(\mathrm{C})$ at $5^{\circ} \mathrm{C}$ (closed bars) and $25^{\circ} \mathrm{C}$ (open bars) in wet shipping solutions (tap water, $\mathrm{ClO}_{2}$, and Chrysal OVB). Lowercase letters indicate mean separation at $p<.05$ by Duncan's multiple range test. Vertical bars represent the standard errors $(n=3)$.
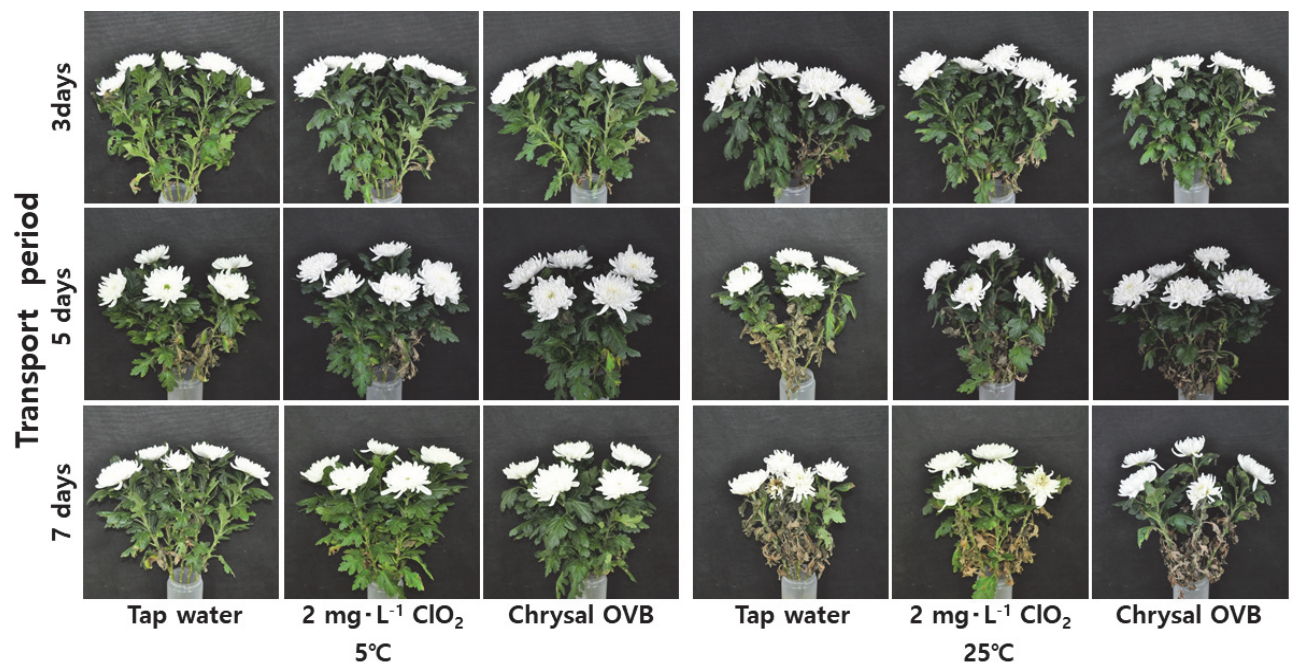

Fig. 6. Quality of cut flower of standard chrysanthemum 'Jinba' at 18 days in holding solution after simulated transport for 3,5 , and 7 days at $5{ }^{\circ} \mathrm{C}$ and $25^{\circ} \mathrm{C}$ in wet shipping solutions (tap water, $\mathrm{ClO}_{2}$, and Chrysal OVB). 
a great increase in flower diameter in preservative solutions until Day 8, showing flower diameter greater than those transported at $25^{\circ} \mathrm{C}$. In particular, it was greatest at $520 \%$ in $\mathrm{ClO}_{2}$ in Day 12, and $497 \%$ in Day 20, showing the greatest flower diameter among all treatments. However, it was $60 \%$ smaller than that of cut flowers transported in $\mathrm{ClO}_{2}$ for 3 days at $5^{\circ} \mathrm{C}$, which indicated that as the transport period increased by 2 days, the quality of cut flowers was deteriorated slightly. Vase life was longest at $5^{\circ} \mathrm{C}$ in $\mathrm{ClO}_{2}$ (16.4 days) and Chrysal OVB (16.0 days), and at $25^{\circ} \mathrm{C}$ in $\mathrm{ClO}_{2}$ (15.6 days). Overall, vase life was short when tap water was used as wet storage solution regardless of transport temperature (Fig. 5B). Moreover, vase life was 1.6 days shorter than when transported in $\mathrm{ClO}_{2}$ and Chrysal OVB for 3 days at $5^{\circ} \mathrm{C}$ (Fig. 6).

After harvesting cut flowers of standard chrysanthemum 'Jinba' and transporting them for 7 days, we put them in preservative solutions and examined the quality of the cut flowers. Cut flowers transported at $25^{\circ} \mathrm{C}$ showed a constant decrease of fresh weight in preservative solutions from $112-112 \%$ right after transport to $97 \%$ in $\mathrm{ClO}_{2}, 69.7 \%$ in tap water and $83.8 \%$ in Chrysal OVB in Day 8, showing a significant quality deterioration. For those transported at $5^{\circ} \mathrm{C}$, fresh weight remained at $104 \%$ in preservative solutions until Day 8 when tap water was used, whereas fresh weight remained higher than other treatments in $\mathrm{ClO}_{2}$ and Chrysal OVB, showing the greatest increase at $111-112 \%$ in Days 8-12 in the preservative solution (Fig. 4A). Flower diameter was $163-178 \%$ right after transport for those transported at $25^{\circ} \mathrm{C}$, which increased in preservative solutions to $395 \%, 493 \%$ and $507 \%$ in tap water, $\mathrm{ClO}_{2}$, and Chrysal OVB until Day 8, after which the flower wilted (Fig. 4B). Diameter of cut flowers transported at $5^{\circ} \mathrm{C}$ increased greatly until Day 16, showing $430 \%, 515 \%$, and $520 \%$ in tap water, $\mathrm{ClO}_{2}$, and Chrysal OVB, thereby showing greater diameter in $\mathrm{ClO}_{2}$ and Chrysal OVB. However, the diameter decreased by $65 \%$ than the flowers transported in $\mathrm{ClO}_{2}$ for 3 days at $3^{\circ} \mathrm{C}$, which showed that as the transport period increased for 4 days, the quality of cut flowers were deteriorated. Vase life was longest at $5^{\circ} \mathrm{C}$ in $\mathrm{ClO}_{2}$ and Chrysal OVB (15.6 days), but it was reduced by 2.4 days compared to cut flowers transported in $\mathrm{ClO}_{2}$ for 3 days at $5^{\circ} \mathrm{C}$ (Fig. $5 \mathrm{C}$ ). The ones transported at $25^{\circ} \mathrm{C}$ showed short vase life of 7.2-8.4 days regardless of wet storage solution, thereby showing no value as a product (Fig. 6).

Overall, as the transport period increased from 3 to 7 days, fresh weight, flower diameter and vase life of cut chrysanthemum 'Jinba' seemed to decrease in preservative solutions. Fresh weight and flower diameter remained higher at $5^{\circ} \mathrm{C}$ than $25^{\circ} \mathrm{C}$, and vase life was also longer. There was no statistical difference in fresh weight and vase life depending on wet storage solution when transported at $5^{\circ} \mathrm{C}$ regardless of the transport period, but flower diameter turned out to be greater in $\mathrm{ClO}_{2}$ than tap water and Chrysal OVB. Therefore, when exporting cut chrysanthemum 'Jinba', it would be most effective to transport them in $\mathrm{ClO}_{2}$ at $5^{\circ} \mathrm{C}$ regardless of the transport period in order to maintain the quality of cut flowers and extend their vase life.

\section{Discussion}

\section{Quality of cut flowers immediately after transport ac- cording to transport period and temperature}

Cut flowers harvested in farms of Korea reach the auction house of the importing country through a long period of transport process, where the quality is evaluated by the auction dealers or importing companies, and thus the quality of cut flowers immediately after transport is very important. In particular, when exporting cut flowers like lilies or chrysanthemums, they must maintain the flower buds from harvest without flowering in order to be evaluated as high quality in the auction house of Japan (Lee and Lee, 2015; Lim et al., 2016). In this study, there was no difference in fresh weight and flower diameter of cut chrysanthemum 'Jinba' according to wet storage solutions at $5^{\circ} \mathrm{C}$ and $25^{\circ} \mathrm{C}$ immediately after transport for 3-7 days. However, those transported for 3 days showed bigger flower buds with increased flower diameter at $25^{\circ} \mathrm{C}$ than $5^{\circ} \mathrm{C}$, with some petals opened up. Moreover, when transported for 5 days and 7 days at $25^{\circ} \mathrm{C}$, the flower buds were even bigger and the petals were opened up, showing early flowering. Therefore, when transporting cut chrysanthemum 'Jinba' at $25^{\circ} \mathrm{C}$, some flower buds opened up immediately after transport or showed early flowering regardless of transport period or wet storage solution, thereby resulting in lack of merchantability. 
In this study, cut flowers transported at $25^{\circ} \mathrm{C}$ for 5 days and 7 days showed wilting leaves or chlorosis immediately after transport. Chlorosis may have occurred due to high transport temperature and humid state from wet storage solutions. The biggest problem in long-term transport of cut flowers is chlorosis on leaves, which occurs often in high-temperature transport (Halevy and Mayak, 1881; Suh and Kwack, 1994). Moreover, according to Roh et al. (2018), about $0.3 \times 10^{3} \mathrm{CFU} \cdot \mathrm{mL}^{-1}$ of bacteria was detected when standard chrysanthemum 'Baekma' went through 4 days of simulated transport at $5^{\circ} \mathrm{C}$ using bactericide $\mathrm{ClO}_{2}$ as the wet storage solution. As shown in this study, when transporting cut flowers at $25^{\circ} \mathrm{C}$ for 5-7 days, there is vascular occlusion due to bacterial propagation even if $\mathrm{ClO}_{2}$ or Chrysal OVB is used as the wet storage solution, which prevents water absorption and thus leads to wilting of leaves.

\section{Quality of cut flowers in preservative solutions ac- cording to transport period and temperature}

When transporting cut flowers for export, the quality of cut flowers is determined by transport period, temperature, or method such as dry or wet storage transport. Yoo and Roh (2015) stated that cut chrysanthemum 'Baekma' showed greater fresh weight and flower diameter in preservative solutions when transported at $5^{\circ} \mathrm{C}$ than $20^{\circ} \mathrm{C}$ or $35^{\circ} \mathrm{C}$, thereby showing more favorable quality of cut flowers and 4 days longer vase life. In this study, cut chrysanthemum 'Jinba' also showed an increase in fresh weight at $5^{\circ} \mathrm{C}$ in preservative solutions regardless of the transport period of 3-7 days, but fresh weight constantly decreased at $25^{\circ} \mathrm{C}$, thereby showing deteriorated quality. Furthermore, cut flowers showed greater diameter and longer vase life at $5^{\circ} \mathrm{C}$ than $25^{\circ} \mathrm{C}$. This may be due to the increased breathing quantity of cut flowers from high transport temperature, which lowers carbohydrate content, reduces fresh weight, and shortens vase life (Petridou et al., 2001; Song and Lee, 1999; Suh and Kwack, 1994). Therefore, cut chrysanthemum 'Jinba' must be transported at $5^{\circ} \mathrm{C}$ rather than $25^{\circ} \mathrm{C}$ regardless of the transport period in order to maintain the quality and extend vase life.

After transporting cut chrysanthemum 'Jinba' at $5^{\circ} \mathrm{C}$ and putting the cut flowers in preservative solution, fresh weight increased more in $\mathrm{ClO}_{2}$ and Chrysal OVB than tap water regardless of the transport period. However, flower diameter was greater in $\mathrm{ClO}_{2}$ than Chrysal OVB when transported for 3 days and 5 days, whereas there was no statistical difference between the two treatments when transported for 7 days. Vase life also did not show a statistical difference between the two treatments, but was 1.2-2 days longer than tap water. Wet storage transport reduces water stress of cut flowers and maintains quality such as fresh weight and flower diameter, and is also effective in extending vase life (Lee and Lee, 2015; Roh et al., 2018). Solutions used for wet storage transport include bactericides such as $\mathrm{NaOCl}, \mathrm{ClO}_{2}$, aluminum sulfate, and 8-hydroxyquinoline sulfate; sugars such as sucrose and fructose; ethylene activator inhibitors such as silver thiosulfate; and commercial products like Chrysal, used by itself or in combination with others (Hu et al., 1998; Lee, 2011; Lee and Kim, 2016; Roh et al., 2017; Uda et al., 2000).

This study used Chrysal and $\mathrm{ClO}_{2}$ as wet storage solutions. Chrysal is commonly used as pretreatment agent or preservative solution after harvesting cut flowers for commercial use (Lee and Kim, 2016). Chrysal OVB promotes water absorption and flowering of cut chrysanthemums after harvest, maintaining fresh conditions for a long time. For exporting cut standard chrysanthemum 'Baekma', fresh weight is known to remain higher when Chrysal OVB is used as the wet storage solution than tap water, but there was no difference in vase life (Roh et al., 2017). $\mathrm{ClO}_{2}$ is a bactericide that is effective in inhibiting propagation of aerobic bacteria in the solutions or sections of cut flowers (Lee and Kim, 2014; Lee et al., 2014; Macnish et al., 2008). Transporting cut chrysanthemum 'Baekma' in 0.5-2 mg • L-1 $\mathrm{ClO}_{2}$ greatly inhibits bacterial propagation, which prevents vascular occlusion of flowers due to bacteria and thus is effective in maintaining quality (Roh et al., 2018).

In this study, we found that when transporting cut flowers at $25^{\circ} \mathrm{C}$, the petals of flower buds open up and the flower diameter increases, which deteriorates quality. Even in preservative solutions, fresh weight and flower diameter decreased compared to when the flowers were transported at $5^{\circ} \mathrm{C}$. If cut flowers must be transported at $25^{\circ} \mathrm{C}$, it was more effective to use $\mathrm{ClO}_{2}$ as the wet storage solution than 
Chrysal OVB in maintaining freshness, but it is not desirable to transport at $25^{\circ} \mathrm{C}$ for more than 7 days. Furthermore, when transporting cut chrysanthemum at $5^{\circ} \mathrm{C}$ for 3-7 days, there was not much difference in fresh weight and vase life between Chrysal OVB and $\mathrm{ClO}_{2}$. However, considering the diameter of cut flowers, it is more adequate to use $\mathrm{ClO}_{2}$ as the wet storage solution than Chrysal OVB.

\section{Conclusion}

Cut chrysanthemum 'Jinba' is a white standard autumn chrysanthemum that naturally flowers in mid- to late October, and it is produced mostly through natural and retarding culture until May in the following year (Roh and Yoo, 2010). Along with white standard chrysanthemum 'Baekma' with cut flowers produced from June to September, 'Jinba' is a variety that is exported the most to Japan. It requires 3-7 days of transport to export cut flowers from Korea to Japan depending on the region, and the quality of cut flowers varies according to transport temperature and method. This study set the transport period at 3 days, 5 days and 7 days, and used wet storage solutions (tap water, $\mathrm{ClO}_{2}$, Chrysal OVB) at the temperature conditions of $5^{\circ} \mathrm{C}$ and $25^{\circ} \mathrm{C}$ to determine the effects on the quality of cut flowers and vase life after wet storage transport.

When transporting cut chrysanthemum 'Jinba' for 3-7 days, the flower diameter increased at $25^{\circ} \mathrm{C}$ and thus resulted in issues such as some petals opening up or flowering early. Even in preservative solutions, fresh weight and flower diameter decreased more significantly when the transport period was longer. Moreover, fresh weight and flower diameter were smaller at $25^{\circ} \mathrm{C}$ than $5^{\circ} \mathrm{C}$, showing deteriorated quality of cut flowers. Vase life was 16.2 days on average when transported at $25^{\circ} \mathrm{C}$ for 3 days, but this decreased significantly to 7.9 days when transported for 7 days.

The flower bud condition from harvest was maintained at $5^{\circ} \mathrm{C}$ even when transported for 3-7 days, and the leaves also showed favorable freshness. In preservative solutions, fresh weight and flower diameter decreased as the transport period became longer, but the decreased amount is smaller than when transported at $25^{\circ} \mathrm{C}$. Overall, fresh weight and flower diameter were greater in $\mathrm{ClO}_{2}$ and Chrysal OVB than tap water, showing better quality and longer vase life. However, there was no difference in fresh weight and vase life between $\mathrm{ClO}_{2}$ and Chrysal OVB, but flower diameter was greater when $\mathrm{ClO}_{2}$ was used as the wet storage solution. Therefore, when exporting cut chrysanthemum 'Jinba', it is effective to use $\mathrm{ClO}_{2}$ as the wet storage solution at $5^{\circ} \mathrm{C}$ for long-term transport in order to maintain quality and extend vase life.

Chrysal OVB is developed by Chrysal International B.V. to maintain freshness of chrysanthemums and is commonly used worldwide. This study also found that using Chrysal OVB as the wet storage solution was more effective for freshness and flower diameter than using tap water. However, the effects were not greater than $\mathrm{ClO}_{2}$ mostly used as a bactericide. Rather, using $\mathrm{ClO}_{2}$ as the wet storage solution was more effective for flower diameter than using Chrysal OVB. Therefore, when exporting cut chrysanthemum 'Jinba', it will be more effective to use $\mathrm{ClO}_{2}$ as the wet storage solution than Chrysal OVB in wet storage transport, both in terms of price or quality.

\section{References}

Bang, C.S. 1999. Effect of pretreatments, holding solutions and shipping conditions on quality and vase life of cut roses. Master's thesis, Chungnam National University, Daegeon, Korea.

Cevallos, J.C. and M.S. Reid. 2001. Effect of dry and wet storage at different temperatures on the vase life of cut flowers. HortTechnology 11(2):199-202. https://doi.org/ 10.21273/HORTTECH.11.2.199

Halevy, A.H. and S. Mayak. 1981. Senescence and postharvest physiology of cut flowers. Hortic. Rev. 3:59-143.

Hu, Y., M. Doi, and H. Imanishi. 1998. Improving the longevity of cut roses by cool and wet transport. J. Jpn. Soc. Hortic. Sci. 67:681-684. https://doi.org/10.2503/jjs hs.67.681

Ichimura, K., T. Yamada, and H. Shimizu-Yumoto. 2009. Recent breakthroughs in postharvest physiology research and cut flower handling in Japan. Hortic. Environ. Biotechnol. 50(6):539-545. 
Lee, H.S. 2011. Effects of cut flower preserve solution for storage and shipping conditions improvement of cut roses. Master's thesis, Chungnam National University, Daejeon, Korea.

Lee, Y.B and W.S. Kim. 2014. Antimicrobial effect of chlorine dioxide on vase life of cut rose 'Beast'. Korean J. Hortic. Sci. Technol. 32(1):60-65. https://doi.org/10.7 235/hort.2014.13090

Lee, H.J. and W.S. Kim. 2016. Effects of pretreatment on quality and vase life of cut lily flowers exported to Japan. Flower Res. J. 24(2):110-116. https://doi.org/10.11623/f rj.2016.24.2.05

Lee, J.H. and A.K. Lee. 2015. Analysis of conveyance environment and pre-treatment on quality maintenance of cut Dendranthema grandiflorum 'Baekma' during ship export to Japan. Korean J. Hortic. Sci. Technol. 33(5): 697-704. https://doi.org/10.7235/hort.2015.15055

Lee, Y.M., S.K. Park, and W.S. Kim. 2014. Antibacterial effect of chlorine dioxide on extending the vase life of cut gerbera 'Jenny'. Flower Res. J. 22(3):161-166. https://doi.org/10.11623/frj.2014.22.3.9

Lim, M.K., S.C. Lee, and W.S. Kim. 2016. Effects of pretreatment and wet storage on quality and vase life of cut lily flowers under simulated exportation. Flower Res. J. 24(2):140-144. https://doi.org/10.11623/frj.2016.24.2.09

Macnish, A.J., R.T. Leonard, and T.A. Nell. 2008. Treatment with chlorine dioxide extends the vase life of selected cut flowers. Postharvest Biol. Technol. 50(2-3):197-207. https://doi.org/10.1016/j.postharvbio.2008.04.008

Ministry of Agriculture, Food, and Rural Affairs. 2019. Present condition of flower production 2018. Jeonju, Korea: Author.

Petridou, M., C. Voyiatzi, and D. Voyiatzis. 2001. Methanol, ethanol, and other compounds retard leaf senescence and improve the vase life and quality of cut chrysanthemum flowers. Postharvest Biol. Technol. 23(1):79-83.
https://doi.org/10.1016/S0925-5214(01)00102-8

Roh, Y.S. and Y.K. Yoo. 2010. Effects of cutting condition on rooting and growth of cut flower in plug cutting of Dendranthema grandiflorum 'Shinma'. Flower Res. J. 18(4):244-250.

Roh, Y.S., I.K. KIm, and Y.K. Yoo, 2017. Vase life and quality of cut flower by $\mathrm{NaOCl}$ and sucrose treatment as wet harvesting solution in standard chrysanthemum 'Baekma'. J. People Plants Environ. 20(5):521-530. https://doi.org/10.11628/ksppe.2017.20.5.521

Roh, Y.S., I.K. Kim, and Y.K. Yoo. 2018. Improved quality and vase life of cut flowers of the standard chrysanthemum cultivar 'Baekma' using wet shipping solutions with $\mathrm{NaOCl}$ and $\mathrm{ClO}_{2}$. Hortic. Sci. Technol. 36(6):863-875. https://doi.org/10.12972/kjhst.2018.0084

Song, C.Y. and J.S. Lee. 1999. Prolonging the vase life of cut chrysanthemum by pretreatments and shipping methods. J. Korean Soc. Hortic. Sci. 40(5):591-594.

Suh, J.N. and B.H. Kwack. 1994. Effects of $\mathrm{GA}_{3}$ and benzylaminopurine on leaf-yellowing of cut chrysanthemum during storage. J. Korean Soc. Hortic. Sci. 35(3):251-257.

Uda, A., M. Yamanaka, A. Yoshino, K. Kawae, and S. Tada. 2000. Maintaining freshness and vase life of cut carnation transported wet with their stems in a pickle with silver thiosulfate (STS) solution. J. Jpn. Soc. Hortic. Sci. 69(4):492-496. https://doi.org/10.2503/jjshs.69.492

van Doorn, W.G., K. Schurer, and Y. de Witte. 1986. Role of endogenous bacteria in vascular blockage of cut rose flowers. J. Plant Physiol. 134(3):375-381. https://doi.org/10.1016/S 0176-1617(89)80259-7

Yoo, Y.K. and Y.S. Roh. 2015. Effects of shipping temperature and harvesting stage on quality and vase life of cut flowers in Dendranthema grandiflorum 'Baekma' for export. Korean J. Hortic. Sci. Technol. 33(1):61-69. https://doi.org/10.7235/hort.2015.14 